\title{
HIDEN MOVEMENT KH. HASYIM ASY'ARI DALAM KAJIAN FIQIH SIYASAH
}

\author{
Muhammad Fahmi Hidayatullah \\ Dosen Fakultas Agama Islam Universitas Islam Malang, Indonesia \\ E-mail:m.fahmihidayatullah@gmail.com
}

\begin{abstract}
The dynamics of the history of independence heroes become an important thing for us to look at together some of the historical literature of struggle, the role of the santri lost from the important fragment in history to make the author want to reveal the movement behind the scenes. The movement is known as isltilah biden movement that represents the struggle of the santri based on fiqh siyasah. Ijtihâd political kyai based fiqih siyasah able to move all the elements from various circles both ideological and identity groups through the fatwa Resolution Jihad. But what we need to know is how the fatwa can be realized and what are the components of the biden movement KH. Hasyim Asy'ari. The purpose of writing this scientific paper to describe the idea and action biden movement KH. Hasyim Asy'ari is based on fiqih siyasah. While research methodology in writing using descriptivequalitative literature.
\end{abstract}

Keywords: Hiden Movement, KH. Hasyim Asy'ari, Fiqih Siyasah

\section{Pendahuluan}

Berdirinya Negara Kesatuan Republik Indonesia tidak pernah terlepas dari jasa dan peran para ulama' yang menghiasi panggung perjuangan kemerdekaan walaupun dalam beberapa sejarah lahirnya Pancasila serta peristiwa pra-kemerdekaan Indonesia tidak dijelaskan secara rinci proses perjuangan kemerdekaan yang disana melibatkan para ulama' termasuk peristiwa perjuangan 10 November yang dilatarbelakangi oleh Fatwa Resolusi Jihad 21-22 Oktober 1945 sebagai konteks perlawanan terhadap penjajah. Padahal kalau kita ingin menulusuri secara mendalam tentang sejarah perjuangan pra kemerdekaan, ada banyak peran ulama' dalam perjuangan tersebut karena memang mayoritas penduduk Indonesia adalah Muslim pasca syiar Walisongo di Jawa. Hilangnya fragment penting dalam sejarah merupakan bias dan historiografi sejarah naisonal yang bernuansa elitis dan politis. 
Ulama' atau kiai ${ }^{1}$ merupakan tokoh yang berperan dalam upaya menumbuhkan kesadaran nasional bangsa Indonesia. Ulama' atau kiai hadir sebagai katalisator yang menggerakkan massa dalam berjuang melawan pemerintah kolonial. Menurut Ali Haidar ${ }^{2}$, sehingga peran ulama' sangatlah sentral dalam proses perubahan sosial kemasyarakatan, karena ulama' merupakan tokoh yang dijadikan panutan bagi seluruh umat Muslim Indonesia.Kiai atau ulama' merupakan sisi penting dalam kehidupan tradisional petani di pedesaan. Keresahan petani akibat tekanan pemerintah kolonial menemukan legitimasi perjuangannnya dengan ayoman kepemimpinan ulama' dalam melakukan protes terhadap penjajah. ${ }^{3}$ Kontribusi besar kepemimpinan ulama' dalam membina masyarakat menjadikannya sebagai panutan yang fatwa-fatwa serta kebijakannya selalu diikuti masyarakat tanpa memikirkannya. Semua itu juga tidak terlepas atas dedikasi yang begitu ikhlas kepada masyarakat melalui pendidikan sepenuh hati (champion public education).

Pendidikan sepenuh hati memiliki kaitan erat dengan konsep bela negara yang terselip dalam agama. Konsep tersebut muncul dalam sebuah agama yang menebarkan benih-benih kasih sayang dan ketulusan dalam melaksanakan suatu perbuatan. Seseorang akan merasakan kemerdekaan bilamana melakukan segala sesuatu dengan ketulusan atas dasar agama. Totalitas dalam melakukan perbuatan menjadi sebuah misi sebuah perjuangan demi memperoleh hasil maksimal dengan suatu tindakan yang berkelanjutan dalam bidang apapun khususnya dalam bidang politik, karena pada dasarnya sebuah perjuangan tidak dapat dipisahkan dari aspek politik yang menjadi bagian dari strategi perang seorang pejuang. Dasar agama juga mempengaruhi seseorang dalam berjuang karena agama pada dasarnya bersifat independenyang secara teoritis dan dogmatis sangat mungkin terlibat dalam kaitan tarik menarik yang saling mempengaruhi dengan kenyataan sosial, ekonomi dan politik.

Salah satu tokoh Muslim Indonesia berpengaruh dalam perjuangan pra-kemerdekaan Indonesia adalah seorang ulama'yang tinggal di daerah plosok pedesaan tepatnya disekitar pabrik gula Cukir Kabupaten Jombang yang saat ini dikenal dengan istilah wilayah Tebuireng. Beliau adalah KH. Hasyim Asy'ari, seorang ulama' merakyat yang bisa masuk

\footnotetext{
${ }^{1}$ Kiai adalah gelar untuk ulama', pemimpin agama, pemimpin pesantren, dan guru senior di Jawa. Dalam Latiful Khuluq, Fajar Kebangunan Ulama': Biografi KH. Hasyim Asy'ari, (Yogyakarta: LKiS, 2000), 5.

2 M. Ali Haidar, Nabdlatul Ulama' dan Islam di Indonesia: Pendekatan Fiqih dalam Politik, (Jakarta: Gramedia Pustaka Utama, 1995), 87.

3 Yusrianto, "Pemikiran Politik Dan Perjuangan KH. M. Hasyim Asy'ari Melawan Kolonialisme" Jurnal Agama dan Hak. Azazi Manusia, Vol. 3, No. 2, Mei 2014, 260
} 
dalam semua lini. Dalam menggerakkan massa (masyarakat dan santri) melawan penjajah beliau memiliki peran andil yang sangat besar dengan gerakan politik yang dilakukannya. Gerakan politik landai tapi tajam mengancam para penjajah yang datang ke daerah tersebut serta menjadi ancaman para penjajah di seluruh penjuru tanah air, karena pengaruhnya yang begitu besar yang tidak hanya mampu menggerakkan masyarakat di daerah tersebut tetapi di seluruh Indonesia melalui gerakan dan pilitik yang dilakukannya. Gerakan yang dilakukannya tidaklah lain adalah gerakan politik biden movement, terstruktur dan sangat masif sebagai sebuah seni dalam memperjuangkan hak asasi manusia dengan wujud kemerdekaan. Dalam tulisan ini penulisan akan mengkaji tentang gagasan dan gerakan KH. Hasyim Asy'ari yang dikenal dengan biden movement dalam kajian fiqih siyasah.

\section{Pembahasan}

Dalam sejarah tidak pernah kita jumpai bahwa KH. Hasyim As'ari seorang pendekar yang memiliki ilmu bela diri ataupun prajurit perang yang terlatih (tentara). Beliau hanyalah manusia biasa seorang abdi bangsa dan negara yang haus akan ilmu pengetahuan serta tidak memiliki background militer sekalipun. Kehausan akan ilmu pengetahuan itulah membuat beliau menggali banyak ilmu pada para ulama' salaf pondok pesantren dalam maupun luar negeri. Tanpa banyak pertimbangan dalam persoalan menuntu ilmu pengetahuan karena bagi KH. Hasyim Asy'ari tujuan pendidikan adalah menjadi manusia yang selalu dekat dengan Allah SWT dan manusia yang menikmati kebahagiaan dunia dan akhirat atas amal perbuatannya. Pengabdian kepada bangsa dan negara diinterpretasikan melalui pendirian pesantren Tebuireng yang berangkat dari filosofi gerakan pembangunan sumber daya manusia serta mengabdikan hidupnya untuk masyarakat walaupun tantangannya sangat besar yang salah satunya adalah melawan penjajah.

Keluasan ilmu pengetahuan serta wawasan bubb al-watan yang dimiliki KH. Hasyim Asy'ari berangkat dari sebuah gagasan dan gerakan. Gagasan yang selalu dikobarkan untuk membebaskan Indonesia dari kungkungan penjajah yang dijadikan sebagai landasan perjuangan bangsa Indonesia salah satunya adalah semangat jihad. ${ }^{4}$ Berjihad membela kebenaran dan menegakkan keadilan melawan penjajah merupakan salah satu sikap yang menjadi prinsip perjuangan KH. Hasyim Asy'ari. Salah

\footnotetext{
4 Mengenai sejarah berdirinya NU: KH. Saifuddin Zuhri, Sejarah Kebangkitan dan Perkembangan Islam di Indonesia (Bandung: PT. Al-Maarif. 1980), Cet. II, 609.
} 
satu landasan perjuangan KH. Hasyim Asy'ari adalah firman Allah SWT dalam Al-Qur'an surat Al-Baqarah ayat 218.

Dalam ayat tersebut dijelaskan bagaimana orang-orang yang beriman, orang-orang yang berhijrah dan berjihad di jalan Allah termasuk kategori orang-orang yang selalu mengharapkan rahmat Allah yang sangat luas. Berjihad di jalan Allah berarti bersiap sedia untuk mendapatkan rahmat dan belas kasih-Nya. Artinya dengan berjihad, bagi KH. Hasyim Asy'ari telah menebarkan kebajikan sekaligus mengharap rahmat Allah untuk kemaslahatan bangsa Indonesia. Dalam konteks ini kita melihat bahwa perjuangan dan pengorbanan Hasyim Asy'ari bagi bangsa Indonesia sangatlah frontal terhadap kebiadaban pemerintah kolonial Belanda, sebabKH. Hasyim Asy'ari tidak ingin menyaksikan kedzaliman merajalela di negerinya. Segala bentuk kemungkaran harus ditumpas dengan amar ma'rûf karena bilmana dilakukan pembiaran hanya akan membuat tatanan kehidupan hancur dan masa depan menjadi suram.

Gerakan KH. Hasyim Asy'ari yang kita kenal dengan biden movement dalam memperjuangkan bangsa Indonesia tidak terlepas dari gerakan Islam dan gerakan politik keagamaan. Adapun gerakan Islam bertujuan kepada tegaknya agama Islam di muka bumi, agar kedamaian, keadilan dan kesejahteraan bagi umat Islam terwujud. Banyak ideologi atau faham yang melandasi gerakan ini. Ada yang bersifat fillah dan sabîlillah. Fillah merupakan gerakan Islam yang menyebarkan ilmu pengetahuan dengan berdakwah. Sedangkan sabîlillah adalah gerakan Islam yang menyebarkan benih kebenaran dengan berperang. Semua gerakan ini bertujuan sama, akan tetapi gerakan ini harus melihat kapan waktu yang tepat untuk menggunakan cara fillah dan fi sabîlillah. Dua metode tersebut menjadi tolak ukur gerakan Islam di Indonesia. ${ }^{5}$ Gerakan Islam yang dilakukan KH. Hasyim Asy'ari disini adalah Islamic Movement of indonesia dalam artian melaksanakan gerakan berdasarkan Islam demi tegaknya negara kesatuan Indonesia.

Konsep gerakan Islamic Movement of Indonesia sebagai sebuah upaya jihad dalam kemerdekaan demi terbentuknya Negara Kesatuan Republik Indonesia. Dua metode jihad yang digunakan tidak secara bersamaan namun menyesuaikan dengan keadaan. Jihad fillah beliau aplikasikan melalui pendidikan pesantren, dakwah baik melalui organisasi sosial kemasyarakatan maupun media majelis ta'lim serta karya yang berbentuk tulisan dalam buku atau kitab. Sedangkan jihad fi sabilillah berdasarkan fatwa Resolusi Jihad yang dikeluarkannya. Sehingga pada tanggal 22

\footnotetext{
${ }^{5}$ http://id.wikipedia.org/wiki/Gerakan_Islam. diakses 10 Oktober 2017 Pukul 18.58. WIB
} 
Oktober 1945, atas dasar kekhawatiran melihat ancaman terhadap negara yang sudah menyatakan proklamasi, fatwa jihad itu dikukuhkan menjadi Resolusi Jihad. ${ }^{6}$ Keberanian KH. Hasyim Asy'ari dalam berjuang melawan penjajah membuktikan bahwa nasionalisme-religius yang tertanam dalam jiwa beliau sangatlah mengakar menjadi satu kesatuan dalam ruh, jiwa dan beliau.

Sedangkan pada abad 20 terdapat dua corak gerakan politik keagamaan yang berkembang, yaitu Islam modernis dan Islam trasidionalis. Islam modernis diartikan sebagai gerakan yang bertujuan menafsirkan kembali doktrin tradisional dengan disesuaikan pada aliranaliran modern dalam filsafat, sejarah dan ilmu pengetahuan. ${ }^{7}$ Adapun Islam tradisionalis diartikan sebagai Islam kultural yang menjunjung tinggi adat istiadat serta kebudayaan. Ada proses akulturasi didalamnya dalam proses penyebaran agama melalui gerakan politik keagamaan.

Islam traditionalis didefiniskan dengan menyikapi segala sesuatu dengan cara berpikir dan bertindak berlandaskan norma dan adat kebiasaan yang telah ada secara turun temurun. Secara etimologi, traditionalis berarti kecendrungan untuk melakukan sesuatu yang telah dilakukan oleh pendahulu, dan memandang masa lampau sebagai otoritas dari segala bentuk yang telah mapan. Kecenderungan traditionalisme Islam Indonesia termasuk kaum elit kultur tradisional identik mengekspresikan Islam kearifan lokal yang tertarik dengan pembaharuan pemikiran keagamaan dan praktik Islam. ${ }^{8}$

Gerakan politik Iskam keagamaan (religious political movement) melalui dua gerakan yakni 1) tradisionalis dan 2) modernis, dimana modernis disebut dengan kalangan muda, sedangkan traditionalis disebut dengan kalangan tua. Dari segi teologis tidak ada perbedaan yang mendasar antar kalangan Islam modernis dan Islam tradisionalis." Lebih ringkasnya merepresentasikan wajah golongan yang hidup pada era reformasi bagi kaum modernis dan golongan tua bagi traditionalis yang berpegang teguh pada mata rantai sejarah serta pemikiran ulama' klasik dalam perilaku keberagamaannya. Dalam hal ini yang mewakili dari kalangan traditionalis adalah KH. Hasyim Asy'ari dalam gerakan politiknya yang menyesuaikan dengan Islam Indonesia (al-Daulat al-Indonesia).

Islam di Indonesia, dalam pandangan Said Aqil Siraj (Ketua Umum PBNU Periode 2010-2015), Islam bukan hanya dîn al-aqîdah wa al-sharîah

\footnotetext{
${ }^{6}$ Gugun El Guyanie, Resolusi Jihad Paling Syar'i (Yogyakarta: Pustaka Pesantren, 2010), 67

${ }^{7}$ Endang Saifuddin Ansharo, Wawasan Islam (Jakarta: Rajawali, 1967), 230-231

${ }^{8}$ Djohan Efendi, Pembaruan Tanpa Membongkar Tradisi (Jakarta: Kompas, 2010) 84

${ }_{9}^{9}$ Djohan Efendi, Pembaruan, 84
} 
(akidah dan syari'ah), tetapi Islam juga agama yang memuat dîn al-ílm wa al-thaqâfah (agama kebudayaan), dîn al-adâb wal hadarah (agama peradaban), dîn al-tahâadum wal madâniyah (agama kemajuan), hal ini yang kemudian Islam bisa diterima dimana-mana seperti Islam di nusantara. Jika Islam hanya aqidah dan syariah maka pasti pengikutnya sedikit, oleh karena disinergikan dengan produk karya manusia, maka Islam diterima di masyarakat dunia, atau Indonesia khususnya. Hal inilah keberadaan Islam di nusantara bisa mengalahkan kerajaan Majapahit, Sriwijaya, dan Padjajaran tanpa mengeluarkan darah sedikitpun. ${ }^{10}$

Berdasarkan kajian diatas bahwa terdapat gagasan gerakan biden movement KH. Hasyim Asy'ari dalam bidang politik sebagai upaya memperjuangan kemerdekaan bangsa Indonesia yang meliputi gerakan Islam Indonesia (Islamic Movement of Indonesia) dan gerakan politik keagamaan (religious political movement). Dalam Islamic Movement of Indonesia beliau mengintegrasikan dua metode jihad yakni konsep jihad fillah dan fi sabilillah. konsep jihad fillah merupakan gerakan dakwah yang didasarkan pada ilmu pengetahuan dan fi sabîlillah merupakan konsep gerakan yang mengarah kepada peperangan melawan penjajah. Adapaun religious political movement KH. Hasyim Asy'ari berorientasi pada gerakan Islam tradisionalis yang menjunjung tinggi pemikiran ulama'yang mengintegrasikan agama dan budaya dengan masuk ke dalam bagian dari rakyat sehingga gerakan politik ini disebut dengan politik merakyat dalam era modern ini yang saat ini menjadi tren politik kepemimpinan pemerintahan sekarang.

Adapun gagasan dan interpretasi gerakan politik tanpa adanya aksi mustahil untuk diwujudkan. Peran sentral KH. Hasyim Asy'ari dalam kemerdekaan menjadi catatan besar dalam sejarah. Kedua gerakan politik diatas diwujudkan melalui mega politik nasional yang diwujudkan dalam political of nationality (politik kebangsaan) yang meliputi 1) ḅubb al-watan, 2) ukhuwah, 3) Laskar Hizbullah, dan 4) Resolusi Jihad. Politik kebangsaan yang mencakup quartologi gerakan inilah yang menjadi aksi dari biden movement KH. Hasyim Ay'ari sebagai bentuk pengabdian dan perjuangan bagi bangsa Indonesia.

Kiblat politik keagamaan KH. Hasyim Asy'ari tidak terlepas dari politik Sunni yang menjadikannya yurispendensi Islam Nahdhatul Ulama' di Indonesia. Empat Imam madzhab menjadi rujukan dalam merumuskan keilmuan ablussunnah wal jama'ah. Prof. Dr. KH. Said Aqil

10 Prof. Dr. KH. Said Aqil Siradj, Dalam Acara Dialog Terbuka Forum Kyai Muda (Pondok Pesantren Bumi Shalawat Sidoarjo-Jawa Timur, 20 Oktober 2009) 
Siradj mengenai ablussunnah wal jama'ab menjelaskan bahwa, pengertian yang selama ini masih dibatasi pada madzhab-madzhab tertentu.

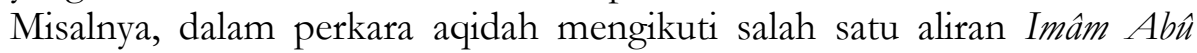
Hasan al-Ash'arî (w.324 H) dan Imâm Abû al-Mansûr al-Matûridî (w.333 H), dalam soal ubudiyah mengikuti salah satu dari Imam Madzhab yang empat yaitu Abu Hanifah (w. 150 H), Malik ibn Anas (W. 179 H), dalam tasawuf mengikuti salah satu dari dua imam besar sufi yakni Ab̂̀ al-Qâsim al-Junaid al-Baghdâdî (w. $297 \mathrm{H}$ ) dan Abû Ḥamid al-Gbazâầ (w. $505 \mathrm{H})^{11}$.

Gerakan politik Sunni ayang dijadikan kiblat politik KH. Hasyim Asy'ari menggambarkan politik merakyat karena dalam konteks ablussunnah wal jama'ah yang dijadikan sebagai dasar aqidah, ubudiyah dan tasawuf mampu mempengaruhi masyarakat untuk turut serta ikut berjuang bersama melalui jihad fi sabilillah demi kebebesan dari penjajah. Energi ASWAJA memantik semangat masyarakat dalam berbagai aspek yang dalam hal ini akidah berkaitan dengan ideologi, ubudiyah berkaitan dengan jiwa dan tasawuf berkaitan dengan raga dan hati nurani sebagai aksi politik kebangsaan.

Ada beberapa karakteristik mengenai pemikiran politik Sunni yaitu, keluwesan dalam menyikapi kondisi politik. Aspek-aspek yang bersifat menentukan sengaja dibiarkan kabur, agar lebih mudah disesuaikan dengan sosial-politik yang baru. Beberapa istilah yang muncul sebagai penguat tentang teori politik Sunni adalah pertama, kejeniusan kelompok Sunni untuk beradaptasi dengan masyarakat dan kedua, sikap memilih diam sebagai output dari realisme itu sendiri. Karena kaum sunni percaya bahwa kegigihan untuk bertahan bukan hanya sekedar sesaat, itu semua bila nasib umat dipertaruhkan, maka itu menjadi sia-sia ${ }^{12}$.

Seni politik sunni menghadirkan gerakan landai tapi tajam, dengan seni gerakan luwes, santun, teguh terhadap pendirian tanpa kompromi dan jenius dalam menyusun strategi peperangan untuk membela tanah air.Atas dasar itulah kemudian pemikiran politik keagamaan KH. Hasyim Asy'ari umumnya sejalan dengan politik sunni, sebagaimana yang dikembangkan oleh ahli fiqih diatas. Karena pada dasarnya, doktrin politik Sunni tersebut yaitu akomodatif terhadap penguasa. Maka $\mathrm{KH}$. Hasyim Asy'ari beserta dengan kolega dan murid-muridnya juga akomodatif terhadap penguasa baik yang Muslim maupun non Muslim. Namun KH. Hasyim Asy'ari punya ketegasan dalam menentukan sikap politiknya. Hal ini bisa dibuktikan ketika KH. Hasyim Asy'ari, murid dan

11 Greg Fealy, Ijtihad Politik. Ulama' (Yogyakarta: LKiS, 2009), 60

12 Greg Fealy, Ijtihad Politik Ulama' ..., 63-64 
koleganya membuat keputusan tentang jihad melawan penjajah atau bisa dikenal dengan Resolusi Jihad. Adapun kontribusi KH. Hasyim Asyari dalam aksi politik kebangsaan berdasarkan ablussunnah wal jama'ah diwujudkan melalui 1) ḅubb al-watan, 2) ukhuwah, 3) Laskar TNI (Hizbullab), dan 4) Resolusi Jihad.

\section{Hụub al-Wațan}

Sebagian umat Islam mempercayai bahwa nasionalisme tidak bertentangan dengan Islam dan bahkan merupakan bagian dari Islam itu sendiri. Seperti pendapat Hassan al-Banna, ia berpendapat bahwa menjadi seorang Muslim yang baik, tidak berarti menjadi seorang yang anti-nasionalisme. Islam tidak bertentangan dengan nasionalisme dan bahkan keduanya bersenyawa. ${ }^{13}$ Fakta inilah yang ditunjukkan oleh para founding father Indonesia, dengan menghadirkan bentuk Negara Kesatuan Republik Indonesia (NKRI) dengan bangunan nation-state sebagai bentuk final yang harus dipertahankan, karena merupakan hasil ijtihad dan jihad umat Islam dalam proses sejarah yang panjang.

Hasan al-Banna dan gerakan Ikhwan-nya pernah dituduh oleh lawan politiknya sebagai tidak punya jiwa dan semangat nasionalisme, ia menolak keras, dan berkata, kalau yang di maksud nasionalisme adalah cinta tanah air, membebaskan negara dari imperialism, merapatkan barisan dan merekatkan tali persaudaraan, maka ia adalah nasionalis sejati. ${ }^{14}$ Pendapat ini disetujui oleh Dr. Yusuf al-Qardhawi dan Dr. M. Imarah. Pada perspektif ini, kita bisa melihat Islam-nasionalisme bersenyawa.

Nasionalisme dengan pengertian paham (ajaran) untuk mencintai bangsa dan negara sendiri dan kesadaran keanggotan dalam suatu bangsa yang secara potensial atau aktual bersama-sama mencapai, mempertahankan, dan mengabadikan identitas, integritas, kemakmuran, dan kekuatan bangsa, ${ }^{15}$ artinya sesorang yang memiliki jiwa hubb terhadap watan adalah yang mau mengabdikan diri dengan perjuangan sampai darah penghabisan demi sebuah kebebasan dengan mengembalikan identitas sebuah negara. Konsep ini tidaklah bertentang dengan agama Islam karena di dalam Islam terdapat konsep hubb al-watan min al-imân yang menjadi tolak ukur kadar keimanan sesorang dengan mencintai

13 Hasan Al-Banna, Risalah Pergerakan Ikhwanul Muslimin, terj. Anis Matta (Solo: Era Intermedia, 2011), 72.

${ }^{14}$ Hasan Al-Banna, Risalah Pergerakan Ikhwanul Muslimin...., 70

15 Kamus Besar Bahasa Indonesia, di akses pada 12 Oktober 2017, pukul 04.38 WIB dari http://kbbi.web.id/nasionalisme 
negaranya melalui konsep cinta yang dimaknai sebagai sebuah proses perjuangan pembebasan dari cerkraman imperealisme, menjaga kehormatan tanpa kompomi dengan mempertahankan politik identitas.

Sikap nasionalisme atau cinta tanah air (bubb al-watan) KH. Hasyim Asy'ari ditunjukkan melalui sikap memaknai hidup sebagai perjuangan dengan politik tanpa berkompromi melawan penjajah dengan cara "mengambil sikap dan jarak" yang sewenang-wenang. Ketegasan dalam membuat keputusan tanpa adanya perubahan ditengah perjalanan melalui berbagai prinsip, komitmen serta kesiapan terhadap berbagai resiko atas keputusan yang diambilnya ditunjukkan melalui satu sikap politik tanpa adanya kompromi adalah penolakan terhadap peristitwa seikerei yang merupakan tradisi dari masyarakat Jepang. Tindakan tersebut merupakan cara penghormatan posisi sebagaimana melaksanakan ruk $\hat{u}$ ' dalam shalat dengan membungkukkan setengah badan menghadap ke arah matahari dan dilakukan pada pagi hari ketika matahari sudah muncul secara sempurna atau penyembahan terhadap kaisar Jepang, Tenno Heika. Tindakan inti sangat bertentangan dengan ideologi dan keyakinan umat Islam dimana ajaran Islam mengajarkan hanya memperbolehkan menyembah kepada Allah. Penyembahan terhadap selain Allah adalah bentuk dosa besar yang dikategorikan syirik. Allah SWT menyebut orang-orang yang telah mempersekutukan sesuatu dengan-Nya sebagai perbuatan zalim. Ayat tersebut dengan tegas mengatakan bahwa Allah mengharamkan surga bagi mereka yang syirik.

Selain syirik, tindakan seikerei bertentangan dengan budaya bangsa Indonesia. Tindakan tersebut sebagai pemicu awal ketegangan antara umat Islam dengan Jepang. Kebijakan seikerei menjadi penyulut api perlawanan terhadap Jepang Pada masa pendudukanJepang itulah agresifitas perjuangan Hasyim Asy'ari semakin terlihat. Penentanganpenentangannya membuat Jepang harus bergerak lebih cepat. Ia sempat ditangkap dan dipenjara selama enam bulan. Hasyim Asy'ari dipenjara karena ia bersama kawan-kawan seperjuangannya menolak melakukan saikerei yang tidak hanya dianggap sesat tetapi juga menyesatkan. ${ }^{16}$

Jepang masuk ke Indonesia sekitar tahun 1942. Dalam Almanak. Asia Raya 2604 disebutkan bahwa awal mula masuknya Jepang adalah dimulai dengan melakukan penyerangan terhadap Sumatera, Jawa, Bali Kalimantan, dan Timor-timor pada bulan Februari 1942. Di bulan ini juga Banjarmasin, Palembang, Denpasar, Dili berhasil dikuasai oleh

16 Yusrianto, "Pemikiran Politik Dan Perjuangan KH. M. Hasyim Asy'ari Melawan Kolonialisme" Jurnal Agama dan Hak Azazi Manusia, Vol. 3, No. 2, Mei 2014, 271 
Jepang. Baru kemudian pada tanggal 1 Maret 1942 Balatentara Da'i Nippon melakukan pendaratan di kota-kota Jawa, seperti Banten, Indramayu, dan Rembang. Berakhirnya kekuasaan Belanda menandai era baru perjuangan politik kalangan Islam dalam memperjuangkan kemerdekaan bangsa. Jepang yang datang dengan wajah lebih ramah telah berhasil memikat hati kalangan Islam. Kebijakan ini sangat berbeda dengan Belanda yang kontraproduktif dengan kekuasaan Ulama'-kiai. Kompromi kebijakan Jepang terhadap kalangan Islam memang telah memberikan peluang besar kepada umat Islam semakin terlibat secara langsung dalam arena perjuangan politik, baik diplomatis atau konfrontatif. $^{17}$

Sebagaimana kita ketahui bersama pada dasarnya kedatangan Jepang ke Indonesia dengan pengakuan sebagai saudara tua yang akan membebaskan Indonesia dari belenggu kolonialisme Belanda. Selain itu pemerintah Jepang berulang kali menyampaikan kedatangannya di Jawa pada Maret 1942 selain tujuan diatas adalah menghargai dan menghormati Islam, janji mereka adalah tidak akan melecehkan umat Islam. Segala bentuk ritual umat Islam tetap berjalan karena memang kedatangan Jepang tidak bermaksud menggangu hal itu, apalagi memaksakan kehendak untuk mematuhi dan mengikuti Jepang. Tujuan jepang hanyalah ingin membantu bangsa Indonesia dari kungkungan penjajah Belanda, Jepang selalu mengatakan tujuannya yang mulia itu dengan sikap yang penuh dengan kearifan dan pengertian Keputusan tersebut cukup berhasil menarik perhatian penguasa dan bangsa Indonesia sehingga Jepang dapat masuk Indonesia dengan mudah tanpa ada perlawanan yang sengit dari bangsa Indonesia. Tidak bertahan lama setelah Jepang mengeluarkan kebijakan melakukan seikerei banyak sekali pertentangan dari bangsa Indonesia utamanya dari kalangan ualama' atau kyai terlebih kebijakan tersebut dilakukan secara pemaksaan yang berdampak terhadap timbulnya konflik yang berkepanjangan atas penghianatan yang dilakukan Jepang.

Kebencian umat Islam terhadap Jepang semakin meruncing pasca keputusan tindakan seikerei sehingga umat Islam Indonesia tidak hanya kecewa tetapi melakukan gerakan perlawanan terhadap jepang. Saifuddin Zuhri menggambarkan bagaimana kebencian para kiai pesantren terhadap kegiatan yang telah dilakukan oleh pemerintah Jepang ini: ${ }^{18}$

\footnotetext{
17 Yusrianto, Pemikiran Politik, 270
}

${ }^{18}$ Y usrianto, Pemikiran Politik, 272 
"Masalah Seikerei ini menimbulkan kegemparan di kalangan ulama' dan dunia pesantren di seluruh tanah air. Membungkukkan badan hingga 90 derajat dengan maksud menghormat sesama manusia biar raja sekalipun, menurut pandangan ulama' adalah haram, dosa besar. Membungkukkan badan semacam itu menyerupai rukêu' dalam sembahyang orang Islam, yang hanya diputuskan menyembah Allah Swt. Selain Allah, biar raja sekalipun, biar katanya Tenno heika adalah Tuhan bangsa Jepang keturunan dewa Amaterasu, dewa di langit sekalipun, haramlah diberi hormat dengan membungkukkan badan hingga 90 derajat bentuknya. Pendirian para ulama' dan dunia pesantren disampaikan pada Saikoo Sikikan, panglima besar tentara Jepang di Jakarta, namun Jepang tidak menggubris. Keharusan Saikerei berjalan terus."

Meruncingnya pertentangan terhadap Jepang, KH. Hasyim Asy'ari berada digarda terdepan yang menolak keras tindakan tersebut dengan mengluarkan fatwa haram dan syirik atas tindakan seikerei. Mewajibkan umat Islam agar tidak terpengaruh dengan permintaan jepang dan tetap teguh dengan prinsip ajaran Islam. Fatwa tersebut menyebar luas kepada pesantren diseluruh penjuru tanah air, yang kemudian fatwa tersebut diikuti oleh masyarakat khususnya kaum santri dan para ulama' sebagai pelaksana utama yang menentang kebijakan jepang.

Progresfitas kiai Hasyim Asy'ari dalam melakukan penolakan terhadap seikerei dengan mengeluarkan fatwa haram dianggap sebagai penghasutan dan penentangan secara terbuka terhadap Jepang. Itulah sebabnya kenapa kemudian beliau dipenjara bersama kiai Ahmad Shiddiq akhir april 1942. Dalam buku Antologi NU, KH. Hasyim dipenjara oleh fasisme Jepang selama empat bulan, dengan waktu berpindah-pindah: dari penjara Jombang, Mojokerto, hingga Bubutan Surabaya, membaur dengan tawanan Sekutu. Namun karena Jepang mendapatkan tekanan dan penentangan dari kaum Muslimin, akhirnya Hasyim Asy'ari kiai dan Ahmad Shiddiq dibebaskan pada tanggal 18 Agustus 1942. Totalitas pengorbanan terhadap tanah air menjadi bagian dari konsep bubb KH. Hasyim Asy'ari mempertaruhkan dirinya hanya untuk kepentingan bangsa, padahal sebagaimana kita ketahui bahwa beliau bukanlah seorang yang ditunjuk atau ambisi menjadi pemimpin negara, akan tetapi pengorbanan beliau murni karna kecintaan terhadap bangsa dan negara Indonesia.

\section{Ukhuwah}

Peristiwa kemerdekaan Indonesia tidak terlepas dari sila ke-3 yakni persatuan Indonesia sebagai filosofi perjuangan bangsa atas berdirinya sebuah negara yang didirikan diatas semua kaum yang ingin menjadi satu 
bangsa dalam satu tatanan kenegaraan NKRI. Jiwa nasionalisme yang mengakar dalam diri KH. Hasyim Asy'ari sebagai modal perjuangan dengan cara mempersatukan umat dengan melibatkan semua kalangan untuk melawan penjajah. Pesatuan umat dari berbagai kalangan khususnya umat Islam menyatukan berbagai kekuatan yang membentuk energi positif karena dasar kebersamaan.

Dalam hal pemikiran nasionalisme KH. Hasyim Asy'ari dapat dilihat pertama kali dari sikap politiknya untuk mengajak umat Islam bersatu dalam aksi bersama. Ajakannya untuk persatuan umat Islam di indonesia dalam berbagai kesempatan didasari oleh kondisi umat Islam indonesia sendiri yang terpecah belah. Dipihak lain, penjajahan Belanda sudah mulai dirasakan mencampuri urusan agama Islam. ${ }^{19}$

Ia menyeru untuk semua umat Islam untuk bersatu melawan imperialisme penjajah, apalagi pada masa itu Islam sedang terpecah karena adanya konflik antara kelompok Islam trasionalis dan modernis. Menurutnya persatuan akan mendorong kesejahteraan negara, peningkatan status rakyat, kemajuan dan kekuatan pemerintah, dan telah terbukti sebagai alat untuk mencapai kesempurnaan. Satu dari banyak tujuan persatuan adalah bersemainya kebajikan yang akan menjadi sebab terlaksananya berbagai ide. ${ }^{20}$ Salah satu ide yang diperjuangkan bersama yaitu tentang terwujudnya kemerdekaan dari penjajah, kemandirian mengelola negara dan terciptanya perdamaian diirngi semangat persatuan tanpa perpecahan di bumi Indonesia.

Salah satu pidatonya yang disampaikan pada muktamar NU ke-11 di Banjarmasin yang berjudul al-mawầiz, KH. Hasyim Asy'ari berusaha mendamaikan perselisihan antara kaum modernis dan tradisionalis. Keduanya yang jelas-jelas sama Islamnya, menuduh satu sama lain sebagai pihak yang telah keluar dari Islam. Ia mengatakan:

"Manusia harus bersatu...agar tercipta kebaikan dan kesejahteraan agar terhindar dari kehancuran dan bahaya. Jadi, kesamaan dan keserasian pendapat mengenai penyelesaian beberapa masalah adalah prasyarat terciptanya kemakmuran. Ini juga dapat mengokohkan rasa kasih sayang. Adanya rasa persatuan dan kesatuan telah menghasilkan kebajikan dan keberhasilan. Persatuan juga telah mendorong kesejahteraan negara, peningkatan status rakyat, kemajuan dan kekuatan pemerintah, dan telah terbukti sebagai alat untuk mencapaikesempurnaan. Satu dari banyak tujuan

19 Muhamad Rifai, KH. Hasyim Asy'ari: Biografi Singkat 1871-1947 (Jogjakarta: Garasi, 2009), 94.

${ }^{20}$ Muhamad Rifai, KH. Hasyim Asy'ari: Biografi Singkat, 95 
persatuan adalah bersemainya kebajikan yang akan menjadi sebab terlaksananya berbgai ide. ${ }^{21}$

Jika kehidupan bernegara ditujukan untuk mewujudkan masyarakat persatuan dan kesatuan, maka tentulah berkenaan dengan umat Islam Indonesia. Maka umat Islam juga harus mengambil peran strategis dan kreatif memajukan Indonesia menuju negara plural yang kuat. Penolakan terhadap nation-state dari sisi lain menunjukkan kekhawatiran berlebihan terhadap subordinasi Islam oleh negara, yang merepresentasikan ketidakberdayaan mengambil peran-peran kreatif dan strategis dalam merealisasikan keIslaman dalam kehidupan kebbinnekaan dalam berbangsa dan bernegara.

Islam dan nasionalisme Indonesia adalah dua sisi mata uang yang saling memberikan makna. Nasionalisme selalu meletakkan keberagaman atau pluralitas sebagai konteks utama yang darinya dapat melahirkan ikatan dasar yang menyatukan sebuah negara bangsaIndonesia. ${ }^{22}$ Dua sisi tersebut juga bagaikan mata rantai yang tidak terpisahkan karena keduanya saling melengkapi ibarat sebuah nafas dan jantung manusia, dalam hal ini manusia diibaratkan sebuah negara. Nasionalisme sebagai wujud keberagaman yang bersatu dari berbagai elemen, sedangkan Islam sebagai pondasi dasar dalam membangun persatuan dalam negara demi terwujudnya kedamaian dan ketentraman yang saling bahu membahu antar bangsa sesuai dengan konsep ukhuwah dalam Islam demi terwujudnya keadilan sosial bagi seluruh rakyat Indonesia. Kontribusi KH. Hasyim Asy'ari dalam menyatukan umat inilah sebagai bagian dari politik kebangsaan dalam penguatan nasionalisme.

\section{Laskar TNI (Hizbullah)}

Ada peran KH. Hasyim Asy'ari dalam pembentukan pasukan militer Indonesia yang terwujud dalam terbentuknya pasukan Hizbullah sebagai pasukan perang yang selalu siap menumpas para penjajah. Terbentuknya laskar Hizbullah sebenarnya berawal dari permintaan Saiko Sikikan karena adanya serangan-serangan sekutu. Pesan tersebut disampaikan oleh Abdul Hamid Ono kepada KH. Wahid Hasyim. Abdul Hamid Ono mengatakan bahwa, Jepang meminta padaku agar pemuda-pemuda Islam memasuki Heinho (serdadu cadangan untuk dikirm ke medan perang), kemudian beberapa pendiri NU menjawab, diantaranya KH. Wahid

\footnotetext{
${ }^{21}$ Abdul Basit Adnan, Kemelut Di NU: Antara Kiai Dan Politisi (Solo: CV. Mayasari, 1982), 3839.

22 Gugun El Guyane, Resolusi Jihad Paling Syar'i, 51.
} 
Hasyim dan kolega-koleganya, akan lebih baik apabila pemuda-pemuda santri dilatih kemiliteran untuk pertahanan di dalam negeri ${ }^{23}$

Kemudian segeralah membincangkan mengenai rencan pembentukan tentara Hizbullah. Diantaranya yaitu Wahid Hasyim, Zainul Arifin, Wahab Hasbullah, Saefuddin Zuhri dan kolega-koleganya. Dari perbincangan itu kemudian Zainul Arifin ditunjuk untuk memimpin tentara Hizbullah, dibawah komando spiritual KH. Hasyim Asy'ari ${ }^{24}$.

Tentara Hizbullah, berdiri pada 4 Desember 1944 di SingosariMalang. Laskar ini merupakan tentara santri yang terdiri dari para pemuda Muslim yang taat, yang berusia antar 18-21 tahun. Kelompok ini pada awalnya berada di bawah Masyumi, dan termasuk tentara yang penting bagi Masyumi pada awal-awal kemerdekaan. Anggota-anggota laskar ini, datang dari berbagai organisasi atau kelompok Islam. Namun dalam hal ini, pemuda pesantren dan anggota Ansor Nahdlatul Ulama' (ANU)-lah pemasok paling besar dalam keanggotaan Hizbullah ${ }^{25}$. Pemuda-pemuda itu kemudian dididik selam enam bulan di Jakarta. Setiap kabupaten diharuskan mengirim lima pemuda-pemuda dari pesantren. Selesai menjalani pendidikan militer, mereka diwajibkan melatih pemuda-pemudi didaerahnya. Bahkan bukan hanya para santri yang mendapatkan pendidikan militer, tetapi para kyai juga mendapatkan pendidikan militer. ${ }^{26}$

23 Mempertahankan sejengka tanah air di dalam negeri akan lebih menggugah semangat pemuda-pemudi kita, dari pada bertempur di daerah yang sangat jauh. Musuh yang sudah berada di kampung halaman kita, lebih kita dahulukan pengusirannya dari pada yang masih jauh di luar tanah air. Lebih baik pemuda-pemudi santri dibentuk tentara Hizbullah seperti halnya dengan PETA. Hizbullah bertugas untuk mempertahnkan Tanah Air Indonesia, dengan alasan menghadapi tentara sekutu di medan perang harus dengan tentara yang sudah terlatih, seperti tentara Dai Nippon. Pemuda-pemuda kita yang harus dilatih kemiliteran mungkin akan menyulitkan tentara yang profesional itu. Lain halnya kalau pertahanan dalam negeri diserahkan pemuda-pemudi kita. Dengan demikian, serahkan pertahanan di dalam negeri kepada putera-puteri tanah air sendiri, sedangkan serdadu-serdau Jepang yang ada disini bisa dikirm ke medan perang menghadapi tentara sekutu. Pada saat itu Abdul Hamid Ono menerima asalkan diberi rencananya secara terperinci. Dan aku jawab, aku sanggupi, beberapa hari ini saya akan menyerahkan rencana yang dimaksud! (Saefuddin Zuhri, Saefuddin Guruku Orang-Orang Dari Pesantren), 300-301

${ }^{24}$ Saefuddin Zuhri, Guruku Orang-Orang Dari Pesantren (Yogyakarta: LKIS, 2007), 300-301

25 ANU sekarang dikenal dengan Gerakan Pemuda Ansor (GP Anson) yang menjadi badan otonom di bawah NU. GP Ansor sendiri telah melakukan pergantian nama dari Nahdlatul Syubkhan (1930), Pemuda NU (PPNU) 1931, kemudian menjadi ANU (1934, dan berganti menjadi GP Anson (1949), (Chairul Anam, Gerak Langkah Pemuda Anshar, Surabaya: Aula, 1990), 17

${ }^{26}$ Saefuddin Zuhri, Guruku Orang-Orang Dari Pesantren, 33. Lantas kenapa pada saat itu dunia pesantren; kyai dan santri saling tarik menarik dan berani masuk ke dalam medan perang 
Dalam buku Sang Kyai, dari catatan sejarah terdapat fakta bahwa tentara Indonesia dibangun mendahului negara.Sebelum republik ini lahir, embrio tentara telah ada dalam wujud laskar-laskar rakyat.Ada banyak macam dan jenis laskar rakyat yang dibentuk atas dasar kelompok, baik kelompok keyakinan ataupun identitas.Laskar Hizbullah adalah laskar yang dibangun atas dasar keyakinan ideologis, sementara tentara pelajar dan Laskar Wanita (Laswi) dibentuk atas dasar identitas.Hal ini, mengacu pada perspektif Y. Hermán Ibrahim, seorang purnawirawan TNI (Tentara Nasional Indonesia). ${ }^{27}$ Hal yang seharusnya tidak difikirkan oleh KH. Hasyim Asy'ari menjadi prioritas pemikiran karena pada dasarnya pemimpin pesantren fokus terhadap dakwah dan pengembangan kajian ilmu keagamaan, akan tetapi beliau justrumembuat sebuah gagasan membentuk pasukan militer dari kaum santri dengan lahirnya Laskar Hizbullah.

\section{Resolusi Jihad}

Kobaran api semangat menggaungkan kemerdekaan mengakar dalam tekad yang muncul dalam diri KH. Hasyim Asy'ari. Berbagai aksi politik yang dilakukannya mulai dari pesantren sebagai pusat pembangunan sumber daya manusia, pendirian organaisasi sebagai sarana perluasan relasi dan pembangunan massa sebagaimana organisasi sosio-kultural seperi organisasi NU, MIAI dan Masyumi dan organisasi sosio-politik seperti Masyumi yang berafiliasi menjadi partai politik, serta politik kebangsaan yang melalui: cinta tanah air, persatuan, pembentukan pasukan militer hingga sampai pada klimaks fatwa Resolusi Jihad yang hukumnya fard 'ain. Gerakan terakhir inilah sebagai puncak gerakan politik KH. Hasyim Asy'ari dimana 2 tahun pasca Resolusi Jihad beliau wafat.

Fatwa Resolusi Jihad dilatarbelakangi oleh situasi yang membahayakan kedaulatan tanah air, sehingga PBNU membuat undangan kepada para konsul NU di seluruh Jawa dan Madura. KH. Hasyim Asy'ari pada saat itu langsung memanggil KH. Wahab Chasbullah, Kyai Bisri Syamsuri dan para kyai lainnya untuk mengumpulkan para kyai se Jawa dan Madura. ${ }^{28}$ Proses pengumpulan kyai se-Jawa-Madura tidaklah sulit bagi beliau, karena banyak sekali relasi dan jaringan massa yang telah dibangunnya melalui organisasi sosial-kultur dan organisasi politik yang telah

fisik? Jawabannya adalah karena pesantren tidak hanya mengajarkan ilmu agama, tetapi juga ilmu pencak silat, ilmu bela diri, kanuragan juga diajarkan dan berjalan sampai sekarang.

${ }^{27}$ Gugun El-Guyane. Resolusi Jihad Paling Syar'i, 108

${ }^{28}$ Gugun El-Guyane. Resolusi Jihad Paling Syar'i, 74 
dirintisnya. Sehingga terjadilah pertemuan di Bubutan-Surabaya, tepatnya di Kantor PB Ansor Nahdlatul Ulama' (ANO) pada tanggal 21-22 Oktober 1945, yang dipimpin langsung KH. Hasyim Asy'ari. Setelah rapat darurat tersebut menemukan titik temu, pada 23 Oktober KH. Hasyim Asy'ari sebagai PB (Pengurus Besar) organisasi NU mendeklarasikan sebuah seruan resolusi jïhad fi sabilillah yang mengorbit dengan sebutan Resolusi Jihad. ${ }^{29}$

Keputusan rapat para alim ulama" NU se-Jawa dan Madura di bubutan Surabaya berbunyi: $:^{30}$ 1) Kemerdekaan Indonesia yang telahdiproklamirkan pada 17 Agustus 1945 wajib dipertahankan, 2) Republik Indonesia sebagai satu-satunya pemerintahan yang sah, wajib dibela dan diselamatkan, meskipun meminta pengorbanan harta dan jiwa, 3) Musuh-musuh Republik Indonesia, terutama Belanda yang datang dengan membonceng tugas-tugas tentara Sekutu (Amerika-Inggris) dalam hal tawanan perang bangsa Jepang, tentulah akan menggunakan kesempatan politik dan militer untuk kembali menjajah Indonesia, 4) Seluru Umat Islam, khusnya warga NU, wajib mengangkat senjata melawan Belanda dan kawan-kawannya yang hendak kembali menjajah Indonesia, 5) Kewajiban tersebut adalah-jihad yang menjadi kewajiban bagi tiap-tiap orang Islam (fard ain) yang berada dalam jarak radius $94 \mathrm{~km}$ (yakni jarak di mana umat Islam boleh melakukan shalat jama' dan qasar). Adapun bagi mereka yang berada di luar jarak tersebut, berkewajiban membantu saudara-saudaranya yang berada dalam jarak $94 \mathrm{~km}$ tersebut.

Fatwa jihad diatas sejalan dengan pemikiran Hasyim Asy'ari dalam sebuah syair yang di tulisnyadalam Muqaddimah al-Qanûn al-Asâsî Jam'iyyah Nabdlatul Ulama"', sebagai berikut:

Sungguh masyarakat tak obah tubuh yang satu,

Dan bagian-bagiannya tak tak obah sperti anggota tubub itu,

Setiap anggota memiliki tugas masing-masing,

Jangan sampai tubuh itu dari anggotanya menjadi asing.

Fatwa Resolusi Jihad menyulut reaksi para mujahidin untuk mempertahankan kemerdekaan Indonesia dan fatwa tersebut adalah terobosan dalam ijtihad yang otentik dan transformatif yang berdasarkan referensi fiqih yang berkaitan dengan ahwal al-sakhsiyyah menjadi landasan dalam perumusan fiqih jihad (siyâsah). Gerakan inilah sebagai penutup dari perjuangan masyarakat, kaum santri dan kyai serta pasukan pembela tanah air dalam mewujudkan bangsa yang bebas dan merdeka terlepas

\footnotetext{
${ }^{29}$ Gugun El-Guyane. Resolusi Jihad Paling Syar'i, 74

${ }^{30}$ Gugun El-Guyane. Resolusi Jihad Paling Syar'i, 74-75
} 
dari belenggu para penjajah sampai puncaknya tanggal 10 November 1945 perjuangan mengusir penjajah pasca kemerdekaan berdasarkan resolusi jidah dilakukan oleh Laskar santri, arek-arek, suroboyo dan Tentara Kemanan Rakyat.

Kontribusi KH. Hasyim Asy'ari sangatlah besar dalam kancah perpolitikan tanah air, walaupun gerakannya tidak nampak dan bukan menjadi bagian dari proklamator kemerdekaan, namun jasa dan pengorbanan beliau menghantui para penjajah. Gerakan politik landai tapi tajam menjadikan penjajah terbirit birit ketakutan. Sehingga sangatlah layak sekali ketika beliau dinobatkan sebagai pahlawan Nasional kemerdekaan dan tidak heran jika sampai saat ini walaupun jasadnya sudah tidak ada, akan tetapi gagasan politiknya menjadi rujukan para generasi calon pemimpin penerus masa depan bangsa Indonesia.

Pelajaran yang dapat kita petik dari perjuangan beliau adalah keikhlasan memperjuangkan Hak Asasi Manusia serta totalitas menjadi pemimpin tanpa adanya pencitraan menjadi pelajaran yang sangat berharga bagi para pemimpin dimasa mendatang. Karena jarang sekali kita jumpai pemimpin yang benar-benar murni memperjuangkan keadilan, apalagi saat ini kita dihadapkan dengan krisis kepemimpinan yang tidak banyak kita jumpai disetiap daerah figur pemimpin yang murni menegakkan keadilan sosial. Bilamana keadilan sosial bisa ditegakkan maka persatuan dan kesatuan bangsa dalam sebuah negara akan berdiri kokoh.

\section{Kesimpulan}

Berdasarkan pembahasan dapat kita simpulkan gagasan dan gerakan KH. Hasyim Asy'ari dalam kajian fiqih siyasah dalam mempertahankan tanah air pasca kemerdekaan dengan gerakan bawah tanah yang dikenal dengan istilah biden movement. Dalam konsep biden movement terdapat dua konsep gerakan yakni gerakan Islam Indonesia (Islamic Movement of Indonesia) dan gerakan politik keagamaan (religious political movement). Gerakan Islamic Movement of Indonesia mengintegrasikan dua metode jihad yakni konsep jihad fillah dan fi sabîililah. konsep jihad fillah melalui gerakan pendidikan dan dakwah berdasarkan ilmu pengetahuan dan fi sabîlillah gerakan peperangan melawan penjajah. Adapaun religious political movement berorientasi pada akulturasi agama dan budaya dalam menyatukan ummat sehingga konsep jihad dalam Islam bisa diterima semua golongan. Adapun konsepsi biden movement di interpretasikan melalui aksi 1) membumikan dan mensyairkan bubb al-watan, 2) menguatkan ukbuwah islamiyah dan bashariyah, 3) membentuk Laskar TNI (Hizbullah), dan 4) 
mengeluarkan Fatwa Resolusi Jihad sebagai Klimaks perjuangan melawan penjajah sampai puncaknya 10 November 1945 yang saat dijadikan sebagai Hari Pahlawan.

\section{Daftar Pustaka}

Adnan, Abdul Basit. Kemelut Di NU: Antara Kiai Dan Politisi. Solo: CV. Mayasari, 1982.

Ansharo, Endang Saifuddin. Wawasan Islam. Jakarta: Rajawali, 1967.

Asy'ari, KH. M. Hasyim. Sang Kiai Fatwa KH. M. Hasyim Asy'ari Seputar Islam Dan Masyarakat, terj. Jamal Ma'mur Asmani. Yogyakarta: Cv. Kalam Yogyakarta, 2005.

Banna (al), Hasan. Risalah Pergerakan Ikhwanul Muslimin, terj. Anis Matta. Solo: Era Intermedia, 2011.

Efendi, Djohan. Pembaruan Tanpa Membongkar Tradisi. Jakarta: Kompas, 2010.

Fealy, Greg. Ijtihad Politik Ulama'. Yogyakarta: LKIS, 2009.

Guyanie (el), Gugun. Resolusi Jihad Paling Syar'i. Yogyakarta: Pustaka Pesantren, 2010.

Haidar, M. Ali. Nabdlatul Ulama' dan Islam di Indonesia: Pendekatan Fiqih dalam Politik. Jakarta: Gramedia Pustaka Utama, 1995.

http://id.wikipedia.org/wiki/Gerakan_Islam. diakses 10 Oktober 2017 Pukul 18.58. WIB

Rifai, Muhamad. KH. Hasyim Asy'ari: Biografi Singkat 1871-1947. Jogjakarta: Garasi, 2009.

Yusrianto. "Pemikiran Politik dan Perjuangan KH. M. Hasyim Asy'ari Melawan Kolonialisme" Jurnal Agama dan Hak Azazi Manusia. Vol. 3, No. 2, Mei 2014

Zuhri, KH. Saifuddin. Sejarah Kebangkitan dan Perkembangan Islam di Indonesia. Bandung: PT. Al-Maarif. 1980, Cet. II.

Zuhri, Saefuddin. Guruku Orang-Orang dari Pesantren. Yogyakarta: LKIS, 2007. 